\title{
Glucose inhibits the insulin-induced activation of the insulin-degrading enzyme in HepG2 cells
}

\author{
O. Pivovarova • Ö. Gögebakan • A. F. H. Pfeiffer • \\ N. Rudovich
}

Received: 19 January 2009 /Accepted: 6 March 2009/Published online: 25 April 2009

(C) Springer-Verlag 2009

\begin{abstract}
Aims/hypothesis Hepatic insulin degradation decreases in type 2 diabetes. Insulin-degrading enzyme (IDE) plays a key role in insulin degradation and its gene is located in a diabetes-associated chromosomal region. We hypothesised that IDE may be regulated by insulin and/or glucose in a liver cell model. To validate the observed regulation of IDE in vivo, we analysed biopsies of human adipose tissue during different clamp experiments in men.

Methods Human hepatoma HepG2 cells were incubated in normal $(1 \mathrm{~g} / \mathrm{l})$ or high $(4.5 \mathrm{~g} / \mathrm{l})$ glucose medium and treated with insulin for $24 \mathrm{~h}$. Catalytic activity, mRNA and protein levels of IDE were assessed. IDE mRNA levels were measured in biopsies of human subcutaneous adipose tissue before and at $240 \mathrm{~min}$ of hyperinsulinaemic, euglycaemic and hyperglycaemic clamps.

Results In HepG2 cells, insulin increased IDE activity under normal glucose conditions with no change in IDE mRNA or protein levels. Under conditions of high glucose, insulin increased mRNA levels of IDE without changes in IDE activity. Both in normal and high glucose medium, insulin increased levels of the catalytically more active 15 a $I D E$ isoform compared with the $15 \mathrm{~b}$ isoform. In subcutaneous
\end{abstract}

adipose tissue, IDE mRNA levels were not significantly upregulated after euglycaemic or hyperglycaemic clamps. Conclusions/interpretation Insulin increases IDE activity in HepG2 cells in normal but not in high glucose conditions. This disturbance cannot be explained by corresponding alterations in IDE protein levels or IDE splicing. The loss of insulin-induced regulation of IDE activity under hyperglycaemia may contribute to the reduced insulin extraction and peripheral hyperinsulinaemia in type 2 diabetes.

Keywords Euglycaemic-hyperinsulinaemic clamp • HepG2 cells · Hyperglycaemic-hyperinsulinaemic clamp · Insulin-degrading enzyme $\cdot$ Subcutaneous adipose tissue · Type 2 diabetes mellitus

$\begin{array}{ll}\text { Abbreviations } \\ \text { EC } & \text { Euglycaemic-hyperinsulinaemic clamp } \\ \text { HC } & \text { Hyperglycaemic-hyperinsulinaemic clamp } \\ \text { HPRT1 } & \text { Hypoxanthine phosphoribosyltransferase 1 } \\ \text { IDE } & \text { Insulin-degrading enzyme } \\ \text { RPLP0 } & \text { Ribosomal protein large protein } 0 \\ \text { qRT-PCR } & \text { Quantitative real-time PCR }\end{array}$

\section{Introduction}

Type 2 diabetes is characterised by insulin resistance, pancreatic beta cell dysfunction, and probably alterations in insulin metabolism $[1,2]$. Decreased hepatic insulin degradation is an early phenotypical marker of disturbances in insulin metabolism and it was observed in first-degree relatives of type 2 diabetes patients [2], in obese insulinresistant persons and children with metabolic syndrome [3-5]. Decreased insulin degradation may intensify insulin 
resistance via chronically elevated circulating fasting and postprandial insulin levels. However, mechanisms leading to the alteration in insulin degradation remain unclear.

Insulin-degrading enzyme (IDE) is thought to be a major enzyme responsible for insulin degradation [6]. IDE is a $110 \mathrm{kDa}$ zinc-requiring metalloproteinase located in the cytoplasm, cell membranes and some cell organelles (endosomes, peroxisomes and mitochondria) and is secreted into the extracellular space [6-8]. Insulin is the preferred substrate for IDE, but a large body of other substrates, including glucagon, atrial natriuretic peptide and $\beta$-amyloid peptide, were reported [6]. IDE has also regulatory functions for proteasome activity, steroid receptors, peroxisomal fatty acid oxidation, growth and development [9-12]. IDE is ubiquitously expressed, both in insulin-sensitive and in non-insulin-sensitive cells, indicating a multifunctional role for this protein [6].

Linkage with the $I D E$ chromosome region, 10q23-q25, was identified for type 2 diabetes and related quantitative traits $[13,14]$. Evidence for a putative influence of IDE on the pathogenesis of type 2 diabetes was confirmed in association studies in several independent human populations [15-17] and in a recently published meta-analysis [18].

$I D E$ knockout mice are characterised by the classic features of type 2 diabetes: decreased insulin degradation, hyperinsulinaemia and glucose intolerance [19]. Loss-offunction mutations or pharmacological inhibition of IDE increases amyloid accumulation in pancreatic beta cells and in the central nervous system [19-21]. On the other hand, IDE overproduction increases insulin degradation and decreases the efficiency of insulin stimulation in the insulin signalling pathway [22]. These data demonstrate that the regulation of IDE expression and/or the activity of the protein may contribute to the pathogenesis of type 2 diabetes.

All insulin-sensitive cells contain IDE and degrade insulin. However, the liver is the main site of insulin clearance, removing approximately $75 \%$ of the insulin during the first portal passage [23]. Few reports have been published concerning the functional regulation of IDE in the liver or in liver cells [24-26].

In the present study, we performed a detailed analysis of the regulation of IDE functions by different concentrations of insulin and glucose in HepG2 cells. In this liver cell model, IDE regulation was analysed at three levels: IDE transcription, IDE mRNA translation and IDE protein activity. Moreover, in humans we assessed the regulation of IDE by different clamped glucose and insulin concentrations in vivo in subcutaneous adipose tissue.

\section{Methods}

Cell culture Human hepatoma HepG2 cells were cultured in DMEM (Biochrom, Berlin, Germany) containing 10\% (vol./vol.) FBS (Gibco/Invitrogen, Eggenstein, Germany) and $1 \mathrm{~g} / 1 \mathrm{D}$-glucose. Cells were incubated in a humidified atmosphere of $5 \% \mathrm{CO}_{2}$ at $37^{\circ} \mathrm{C}$. For experiments, HepG2 cells were maintained in complete medium with $10 \%$ (vol./vol.) FBS and either normal (1.0 g/l) or high (4.5 g/l) concentrations of D-glucose for $48-72 \mathrm{~h}$ to $80 \%$ confluence. Incubation of cells in high-glucose medium was used as a model of insulin resistance [27]. After $24 \mathrm{~h}$ of serum starvation cells were treated with $0.1,1,10,100$ or $200 \mathrm{nmol} / \mathrm{l}$ insulin (Sigma Aldrich, Taufkirchen, Germany) for $24 \mathrm{~h}$. As an osmotic control, $3.64 \mathrm{~g} / 1$ mannitol (Sigma Aldrich) was added to normal glucose medium in simultaneous wells.

RNA extraction Total RNA from subcutaneous adipose tissue biopsy samples was extracted using the RNeasy Lipid Tissue Mini Kit (Qiagen, Hilden, Germany). Total RNA was extracted from HepG2 cells with Trizol reagent (Invitrogen, Karlsruhe, Germany) according to the manufacturer's instructions. The RNA concentration was measured and quality controlled using an ND-1000 spectrophotometer (Nanodrop, PeqLab, Erlangen, Germany).

Reverse transcription PCR (RT-PCR) First-strand cDNAs were synthesised with TaqMan Reverse Transcription Reagents (Applied Biosystems, Darmstadt, Germany) using random hexamers as described in the manufacturer's instructions. To search alternatively spliced transcript variants of different size, RT-PCR was carried out using cDNAs as templates with TaqDNA polymerase (Invitrogen) and corresponding primers as described previously [28]. In brief, RT-PCR with four different primer pairs spanning the entire IDE coding region (IDE 1F/IDE 5R, IDE 6F/IDE 13R, IDE 14F/IDE 19R, IDE 20F/IDE 25R) (Table 1) was performed in an thermal cycler (Eppendorf, WesselingBerzdorf, Germany). The thermal cycling conditions were as follows: initial denaturation at $94^{\circ} \mathrm{C}$ for $2 \mathrm{~min}$, followed by 35 cycles of $45 \mathrm{~s}$ of denaturing at $94^{\circ} \mathrm{C}, 45 \mathrm{~s}$ of annealing at $60^{\circ} \mathrm{C}$, and $45 \mathrm{~s}$ of extension at $72^{\circ} \mathrm{C}$, and final incubation at $72^{\circ} \mathrm{C}$ for $10 \mathrm{~min}$. RT-PCR products were separated on $1.5 \%$ (wt/vol.) agarose gel.

Quantitative real-time PCR Quantitative real-time PCR (qRT-PCR) was performed in a 384-well plate in an ABI Prism 7700 sequence detection system (Applied Biosystems). Quantitative real-time PCR was carried out on equal amounts of cDNA in triplicate for each sample from three independent experiments using Power SYBR Green PCR Master Mix (Applied Biosystems). The thermal cycling conditions for qRT-PCR were as follows: initial denaturation at $95^{\circ} \mathrm{C}$ for $10 \mathrm{~min}$, followed by 47 cycles of denaturing at $95^{\circ} \mathrm{C}$ for $15 \mathrm{~s}$, and annealing/extension for $1 \mathrm{~min}$ at $60^{\circ} \mathrm{C}$. Quantification of mRNA levels was 
Table 1 Primers used in the present study

\begin{tabular}{|c|c|c|}
\hline Gene & Primer & Sequence \\
\hline \multirow[t]{14}{*}{$I D E$} & IDE_real_F1 & 5'-AGGCCACGGGGCTATACAT-3' \\
\hline & IDE_real_R1 & 5'-CTATGGCAACCCGGACATTTT-3' \\
\hline & IDE_real_F2 & 5'-CCCTAGACAGGTTTGCACAGTTT-3' \\
\hline & IDE_real_R2 & 5'-ACTGCATTCACCTCTCTGTCTTTG-3' \\
\hline & IDE $1 \mathrm{~F}$ & 5'-GCAAGCAGGAAGCGTTTG-3' \\
\hline & IDE 5R & 5'-CAATGCCTTCTTGGTTTGGT-3' \\
\hline & IDE $6 \mathrm{~F}$ & 5'-CCTGAACACCCTTTCCAAGA-3' \\
\hline & IDE $13 R$ & 5'-AAGAGCAGGGTATGGTGTCG-3' \\
\hline & IDE $14 \mathrm{~F}$ & 5'-CCGAAGGCTTGTCTCAACTT-3' \\
\hline & IDE $15 \mathrm{a}-\mathrm{R}$ & 5'-ATACATCCCATAGATGGTATTTTGG-3' \\
\hline & IDE $15 b-R$ & 5'-TGCATTCATTCCTGATGCAATGC-3' \\
\hline & IDE $19 R$ & 5'-AACCAGCTGACTTGGAAGGA-3' \\
\hline & IDE $20 \mathrm{~F}$ & 5'-GAGGATGGTTTGTTTATCAGCAG-3' \\
\hline & IDE $25 \mathrm{R}$ & 5'-AAAGTGGCCAAGATGATTTTC-3' \\
\hline$R P L P O$ & & QuantiTect Primer Assay (Qiagen) \\
\hline \multirow[t]{2}{*}{$H P R T 1$} & HPRT1 F & 5'-TGACACTGGCAAAACAATGCA-3' \\
\hline & HPRT1 R & 5'-GGTCCTTTTCACCAGCAAGCT-3' \\
\hline
\end{tabular}

performed by the standard curve method. IDE expression in the cell experiments was measured using IDE_real_F1/ IDE_real_R1 primers and normalised to the hypoxanthine phosphoribosyltransferase 1 (HPRT1) gene as internal control. IDE expression in adipose tissue biopsy samples was measured using IDE_real_F2/IDE_real_R2 primers and normalised to the ribosomal protein large protein 0 (RPLP0) gene. The RPLP0 QuantiTect Primer Assay was purchased from Qiagen.

For the determination of exons 15a- and 15b-specific IDE mRNA levels, previously described primers were used [28]. All other oligonucleotides for qRT-PCR were designed with Primer Express software (PE Applied Biosystems, Darmstadt, Germany). PCR primer pairs for qRT-PCR were located in different exons to prevent possible amplification of genomic DNA. Sequences of all primers used are listed in Table 1.

Western immunoblotting HepG2 cell protein extracts were prepared in cell lysis buffer (Cell Signaling, Frankfurt, Germany), sonicated and centrifuged at $700 \mathrm{~g}$ for $10 \mathrm{~min}$ to remove cell debris. Protein concentrations in total cell lysates were measured by the bicinchoninic acid assay (Pierce/Thermo Scientific, Schwerte, Germany) using a Wallac Victor2 multilabel plate reader (PerkinElmer, Freiburg, Germany). Lysates were separated by $12 \%$ (vol./ vol.) SDS-PAGE and electrophoretically transferred to polyvinylidene difluoride membranes (Millipore, Schwalbach, Germany). The membranes were blocked with 5\% (wt/vol.) non-fat dry milk in Tris-buffered saline with $0.1 \%$ (vol./vol.) Tween 20 and hybridised with the appropriate primary antibodies: rabbit IDE antibody $(1: 1,000$; Chemicon, Hofheim,
Germany) or rabbit $\beta$-actin antibody (1:2,000; Sigma Aldrich), followed by incubation with anti-rabbit horseradish peroxidase-conjugated secondary antibodies $(1: 2,000$; Cell Signaling Technology). Immunoreactive bands were visualised using the Lumiglo chemiluminescence detection system (Cell Signaling Technology). The chemiluminescence signal was quantified using a CCD camera and Image Reader LAS-1000 Pro v 2.1 software (Fujifilm, Tokyo, Japan) and an AIDA Image Analyzer (Raytest, Straubenhardt, Germany). Relative IDE protein levels were calculated by normalisation of the IDE levels with $\beta$-actin signals, and mean values from three independent experiments were taken.

IDE activity assay HepG2 cells were disrupted by scraping in CytoBuster Protein extraction reagent (Novagen, Schwalbach, Germany) for the preparation of total cell extracts or hypotonic buffer $(50 \mathrm{mmol} / \mathrm{l}$ Tris- $\mathrm{HCl}, \mathrm{pH} 7.4)$ for the preparation of membrane and cytosolic fractions, followed by $30 \mathrm{~min}$ incubation and extrusion through a 23gauge hypodermic needle. Membrane and cytosolic fractions were prepared as described previously [28]. In brief, the post-nuclear supernatant fraction was centrifuged at $100,000 \mathrm{~g}$ for $1 \mathrm{~h}$ to separate cytosolic (supernatant fraction) and membrane (pellet) fractions. The pellet was resuspended in $100 \mu \mathrm{l}$ of $50 \mathrm{mmol} / \mathrm{l}$ Tris- $\mathrm{HCl}(\mathrm{pH} \mathrm{7.4)}$ and stored at $-80^{\circ} \mathrm{C}$.

The traditional insulin degradation assay using ${ }^{125} \mathrm{I}$-labelled insulin and trichloroacetic acid [21, 28] requires radioactive material to be handled. Therefore, IDE activity was assessed with the non-radioactive InnoZyme Insulysin/ IDE Immunocapture Activity Assay Kit (Calbiochem/Merck, Schwalbach, Germany) which has an effective working 
range of $50-1,000 \mathrm{ng} / \mathrm{ml}$. Fluorometric quantification of insulin degradation by membrane samples was performed using the FRET substrate (Mca-GGFLRKHGQEDDnp), which is a component of the InnoZyme Insulysin/IDE Immunocapture Activity Assay Kit. For this assay, membrane suspensions were diluted 1:75 in $50 \mathrm{mmol} / 1$ Tris- $\mathrm{HCl}$. Five microlitres of the diluted membrane fraction was incubated with $100 \mu 1$ of $1 \times$ FRET substrate solution in assay buffer for $3.5 \mathrm{~h}$ at $37^{\circ} \mathrm{C}$. Sample fluorescence was determined at an excitation wavelength of $320 \mathrm{~nm}$ and an emission wavelength of $405 \mathrm{~nm}$ on a SpectraMax M2e plate reader (Molecular Devices, Ismaning, Germany). Reactions were performed in duplicate for samples from three independent experiments, and the percentage of hydrolysis was calculated from standards containing rat recombinant IDE. Enzyme activity was assessed as relative fluorescent units per $\mathrm{mg}$ of total protein. Protein concentration was determined by the bicinchoninic acid assay (Pierce).

Glucose clamp studies The study protocol was approved by the ethics committee of Brandenburg (registration number: AS 2(a)/2005), Germany. Before the study, informed written consent was obtained from all participants.

Seventeen healthy non-diabetic men with moderate obesity participated in two of the following procedures: (1) an infusion test with placebo (infusion of $0.9 \%$ [wt/ vol.] $\mathrm{NaCl}$ solution) ( $n=11)$; (2) a hyperinsulinaemiceuglycaemic clamp (EC) with continuous infusion of 240 pmol m $\mathrm{m}^{-2} \mathrm{~min}^{-1}$ insulin at a steady-state capillary plasma glucose concentration of $4.4 \mathrm{mmol} / \mathrm{l}(n=10)$; (3) a hyperinsulinaemic-hyperglycaemic clamp (HC) with continuous infusion of $240 \mathrm{pmol} \mathrm{m}^{-2} \mathrm{~min}^{-1}$ insulin at a steadystate capillary plasma glucose concentration of $7.8 \mathrm{mmol} / 1$ $(n=8)$.

For all clamps, human insulin (Actrapid; Novo Nordisk, Bagsværd, Denmark) and glucose (Serag Wiessner, Naila, Germany) were used. Throughout the clamp, plasma glucose concentrations were monitored every $5 \mathrm{~min}$ and used to regulate plasma glucose by the adjustment of a variable infusion of glucose. A deviation of a single capillary glucose concentration of $>10 \%$ during assumed steady-state conditions was defined as non-steady state. In the hyperinsulinaemic-hyperglycaemic clamp, $150 \mathrm{mg}$ diazoxide (Proglycem; Schering, Berlin, Germany) was given twice (at -60 and $120 \mathrm{~min}$ of the experiment) in combination with constant, continued insulin infusion for the suppression of endogenous insulin secretion. Deviation of the plasma insulin concentration was $<10 \%$ during the steady state. All tests were conducted for $240 \mathrm{~min}$. Subcutaneous adipose tissue biopsy samples were taken $40 \mathrm{~min}$ before the start of insulin/placebo infusion and at the end (240 $\mathrm{min})$ of clamp tests. After removal, tissue samples were frozen in liquid nitrogen and stored at $-80^{\circ} \mathrm{C}$ until total RNA isolation.
Statistical analysis All values are expressed as mean \pm SD. Differences between means were analysed using two-tailed Student's $t$ test. A $p$ value $<0.05$ was considered statistically significant. Statistical analyses were performed with SPSS 14.0 (SPSS, Chicago, IL, USA).

\section{Results}

IDE expression in HepG2 cells in the presence of different insulin concentrations For the detailed analysis of IDE regulation, the hepatoma HepG2 cell line was chosen as a liver cell model. HepG2 cells maintained in normal glucose medium $(1 \mathrm{~g} / \mathrm{l})$ were treated with $0.1,1,10,100$ and $200 \mathrm{nmol} / \mathrm{l}$ insulin for $24 \mathrm{~h}$. These insulin concentrations induced no alterations of IDE mRNA levels measured by qRT-PCR or IDE protein levels as assessed by quantitative western blotting (Fig. 1a, c).

IDE expression in HepG2 cells under normal and high glucose concentrations We compared IDE mRNA and protein levels in HepG2 cells in normal $(1 \mathrm{~g} / \mathrm{l})$ or high ( $4.5 \mathrm{~g} / \mathrm{l})$ concentrations of D-glucose. Mannitol treatment, used as an osmotic control, induced no changes in $I D E$ expression (data not shown). High glucose concentrations alone induced no effects on the mRNA level of $I D E$, while $10 \mathrm{nmol} / 1 \mathrm{insulin}$ induced a significant increase in $I D E$
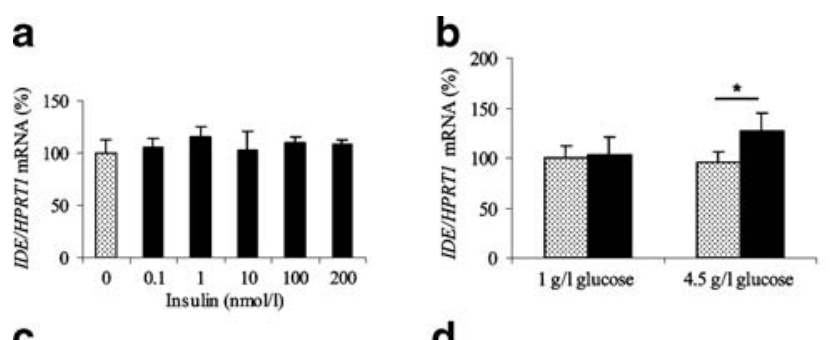

C
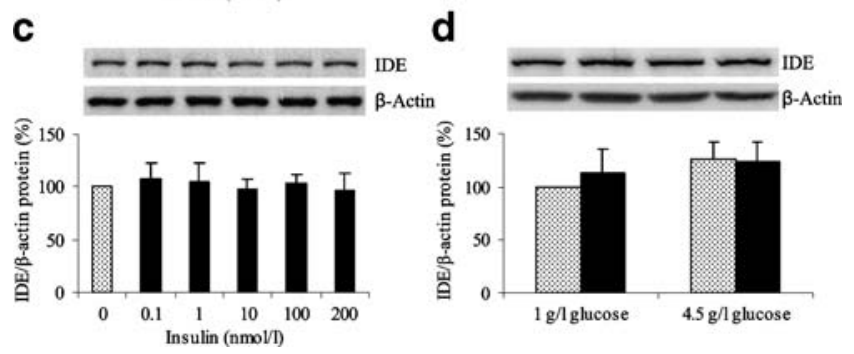

Fig. 1 The influence of insulin and glucose on $I D E$ expression in the HepG2 cell model. IDE mRNA levels were measured in cDNA samples by qRT-PCR and normalised to HPRT1 mRNA levels (a, b). IDE protein levels were determined by quantitative western blot analysis and normalised to $\beta$-actin protein levels (c, d). Representative blots are shown. Data are expressed as percentages of control. Dotted columns, insulin-untreated cells; black columns, insulin-treated cells. a, c IDE expression in cells treated with the indicated insulin concentrations for $24 \mathrm{~h}$ in normal glucose concentration. b, d $I D E$ expression after treatment with $10 \mathrm{nmol} / 1$ insulin for $24 \mathrm{~h}$ under normal and high glucose concentrations. ${ }^{*} p<0.05$ 
Table 2 Absolute IDE activity detected in HepG2 cell samples $(n=3)$

mRNA in a high glucose concentration, in comparison with untreated cells (Fig. 1b). Western blotting of total protein extracts revealed no significant effects of glucose on IDE protein level, with a trend to increased IDE protein levels in the high glucose condition (Fig. 1d). IDE protein levels in cytosolic and membrane fraction of cell samples also did not exhibit significant alterations after insulin or/and high glucose treatments (data not shown).

High glucose inhibits the effect of insulin on IDE activity in HepG2 cells Alteration of enzyme activity might be a mechanism of regulation of IDE function. Therefore, IDE activity was assessed in total protein extracts and cytosolic and membrane fractions prepared from HepG2 cell samples. The absolute values of the IDE activity detected in cell samples (Table 2) were normalised to the total protein concentration of samples. Treatment with $10 \mathrm{nmol} / \mathrm{l}$ insulin significantly increased IDE total catalytic activity $(\sim 1.8$ fold) in the normal glucose condition. Remarkably, this effect was lost in the high glucose condition (Fig. 2a). Cytosolic activity of IDE demonstrated the same effects (Fig. 2b), whereas the peptidolytic activity of membraneassociated IDE was not affected (Fig. 2c). However, a trend to an insulin-induced decrease in IDE activity in the membrane fraction in normal glucose medium was detected.

Search for alternative IDE transcripts of different sizes in insulin- and glucose-treated cells Because altered splicing of IDE mRNA may account for the observed regulation of IDE activity after insulin treatment, we assessed alternative splicing of IDE mRNA by RT-PCR using four primer pairs spanning the entire $I D E$ coding region (Fig. 3a). As shown in Fig. $3 b$, no changes in the sizes of PCR products were observed under high glucose concentrations and/or after insulin treatment for $24 \mathrm{~h}$. No alternative IDE splicing forms of different sizes were detected in the cell samples investigated.

Insulin treatment increases the 15a/15b IDE isoform ratio The IDE isoform produced by the transcript in which exon $15 \mathrm{~b}$ replaces canonical exon $15 \mathrm{a}$ has been reported to have less catalytic efficiency for insulin and amyloid $\beta$-protein compared with the wild-type isoform [8]. Therefore, our next hypothesis was that insulin and/or glucose may alter the $15 \mathrm{a} / 15 \mathrm{~b}$ isoform ratio in HepG2 cells. We assessed the levels of the 15a and 15b IDE mRNA by qRT-PCR using a common forward primer residing in exon 14 and exon 15-specific reverse primers for exons $15 \mathrm{a}$ and 15b (Fig. 4a, b). After treatment with $10 \mathrm{nmol} / 1$ insulin, the level of the 15a isoform of IDE demonstrated a trend to an increase in normal glucose medium and was significantly increased in the high glucose condition compared with untreated cell samples (Fig. 4c), whereas insulin and/or high glucose induced no alteration in $15 \mathrm{~b}$ isoform transcription (Fig. 4d). The ratio of $15 \mathrm{a} I D E$ to $15 \mathrm{~b} I D E$ mRNA was also significantly increased after insulin treatment, independently of glucose concentration in the cell medium (Fig. 4e).

IDE $m R N A$ expression in human subcutaneous adipose tissue after the clamps To study the regulation of IDE expression by insulin and glucose in vivo in humans, we

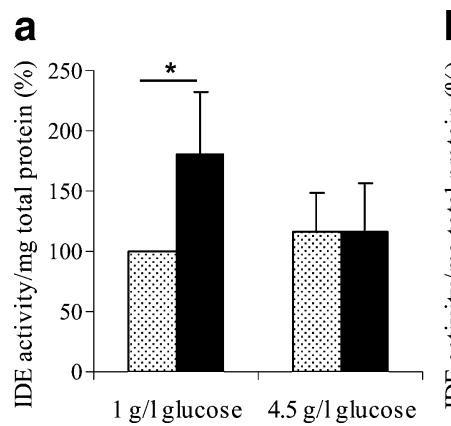

Fig. 2 Effects of insulin and glucose on catalytic activity of IDE in HepG2 cells. Enzyme activity was assessed as relative fluorescent units per $\mathrm{mg}$ total protein. Data are percentages of control activity.
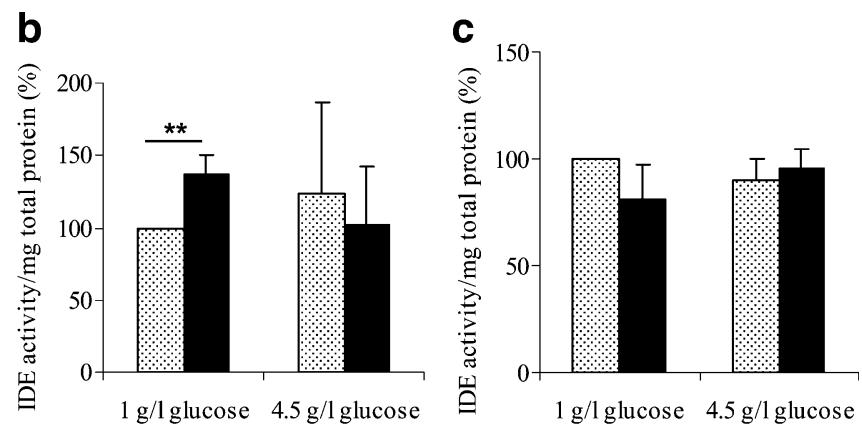

Dotted columns, insulin-untreated cells; black columns, cells treated with $10 \mathrm{nmol} / 1$ insulin. a Total cell lysate; b cytosolic fraction; c membrane fraction. ${ }^{*} p<0.05 ; * * p<0.01$ 
Fig. 3 Expression of alternative $I D E$ transcripts in HepG2 cells treated with insulin and glucose. a Conventional exon structure of IDE transcript. Forward and reverse PCR primer positions are indicated by arrows. I-IV, RT-PCR products. b Products of RT-PCR (I-IV) obtained from cDNA from HepG2 cells treated with insulin and glucose using the four indicated primer pairs a

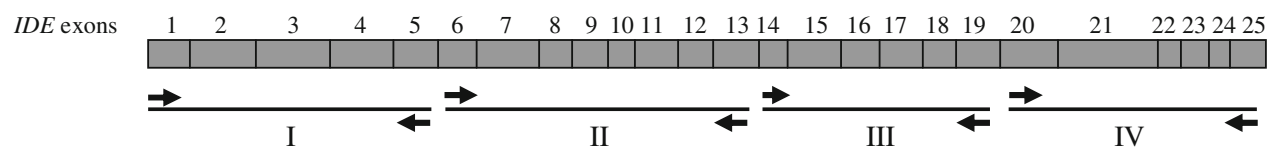

b

I

II

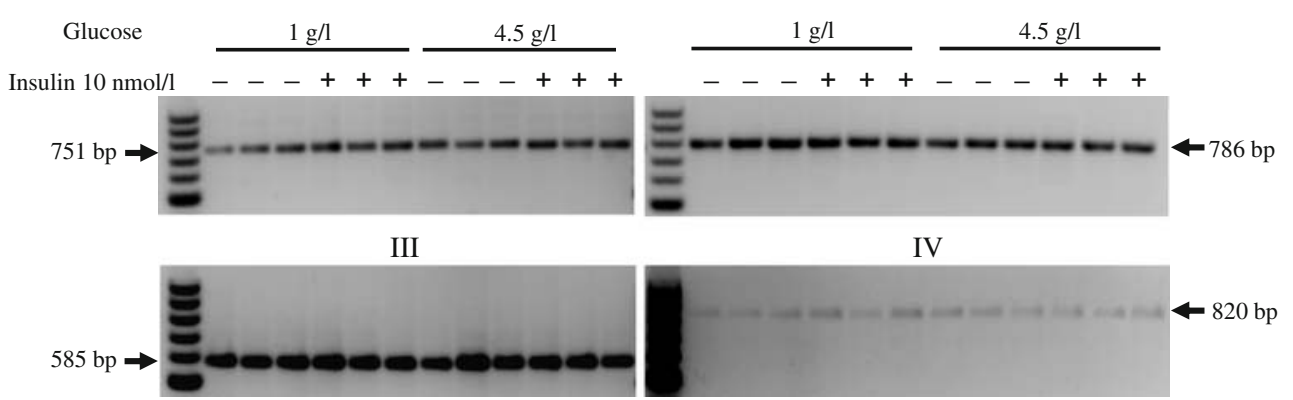

performed qRT-PCR in cDNA from subcutaneous adipose tissue taken before $(-40 \mathrm{~min})$ and after $(240 \mathrm{~min})$ the clamp procedures. Seventeen healthy obese non-diabetic men (age $47.4 \pm 8.4$ years, BMI $32.5 \pm 2.2 \mathrm{~kg} / \mathrm{m}^{2}$, waist circumference $110.5 \pm 7.1 \mathrm{~cm})$ participated in clamp experiments.

$I D E$ mRNA levels were highly variable among the individuals studied $(22.5 \pm 13.5 \%)$. No correlations between IDE mRNA levels in subcutaneous adipose tissue and anthropometric data (age, BMI, waist circumference, percentage of body fat) and basal and steady-state insulin and glucose concentrations were detected (data not shown).

In EC, we studied the effects of high insulin concentrations on IDE mRNA levels in the presence of normal glucose concentration, and in $\mathrm{HC}$ we studied simultaneous effects of high insulin and high glucose concentrations (Fig. 5a, b). In the $\mathrm{NaCl}$ infusion test, no alterations in $I D E$ expression were observed. However, in EC a trend towards an increase in $I D E$ mRNA levels at the end of the clamp test was observed (increase of $17.1 \%, p=0.097$ ) and the increase was more pronounced in $\mathrm{HC}$ (increase of $45.6 \%$, $p=0.091)($ Fig. 5c).

\section{Discussion}

The regulation of IDE activity in insulin-sensitive tissue in health and type 2 diabetes is very poorly understood. We performed a detailed analysis of the regulation of IDE a
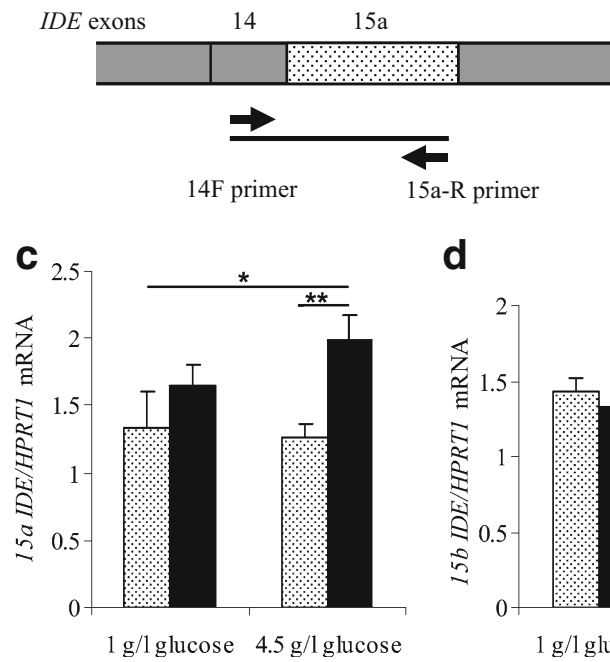

d

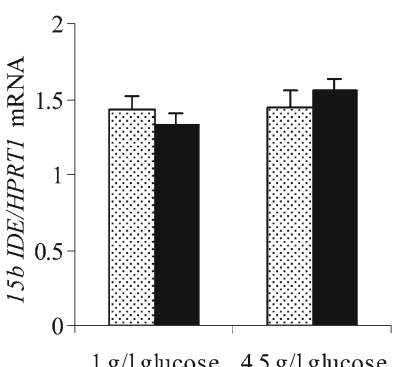

b

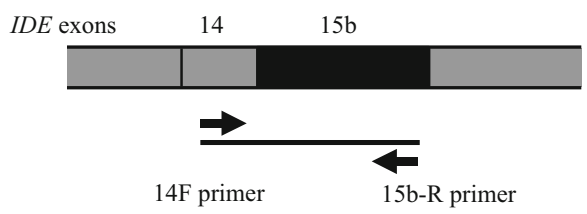

e

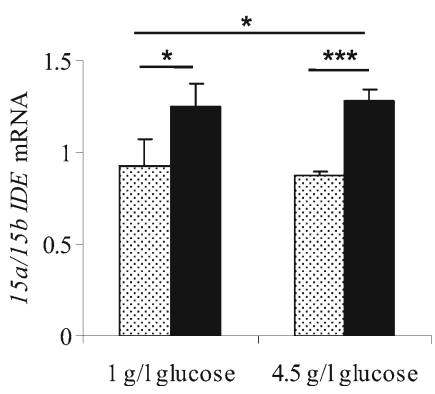

Fig. 4 Effects of insulin and glucose on levels of $15 \mathrm{a}$ and $15 \mathrm{~b}$ IDE isoforms in HepG2 cells. a, b Positions of forward (14F) and reverse $(15 \mathrm{a}-\mathrm{R} / 15 \mathrm{~b}-\mathrm{R})$ primers used for detection of $15 \mathrm{a} / 15 \mathrm{~b}$ mRNA levels of $I D E$ isoforms by exon-specific qRT-PCR. $\mathbf{c}$ Levels of 15a IDE mRNA. d Levels of $15 \mathrm{~b} I D E$ mRNA. e $15 \mathrm{a} / 15 \mathrm{~b}$ ratios in control vs insulinand/or glucose-treated cell samples. Dotted columns, insulin-untreated cells; black columns, cells treated with $10 \mathrm{nmol} / 1$ insulin. ${ }^{*} p<0.05$; $* * p<0.01 ; * * * p<0.001$ 


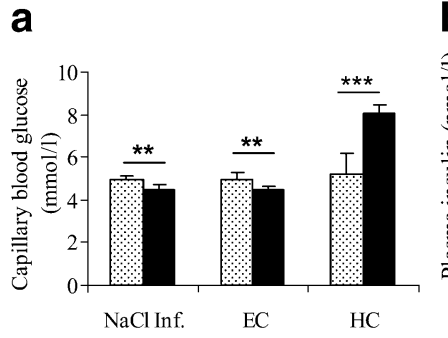

Fig. 5 The influence of insulin and glucose on $I D E$ mRNA levels in human subcutaneous adipose tissue in the clamp study. a Capillary blood glucose. b Plasma insulin (dotted columns, basal values; black columns, steady-state values). c $I D E$ mRNA levels. Data are percentages of basal IDE mRNA levels. Dotted columns, biopsy samples taken before the

function by insulin and glucose in a human hepatoma cell line because data for liver cells are controversial. Our data provide the first evidence of increased IDE activity in hepatoma cells after insulin treatment in normal glucose conditions. Neither insulin nor glucose treatment altered IDE mRNA or protein levels in HepG2 cells at normal glucose concentration. At high glucose concentration, an insulin-induced change in IDE activity was not detectable, but we observed a trend to upregulation of IDE protein levels. Moreover, in normal and high glucose medium, insulin increased levels of the catalytically more active $15 \mathrm{a}$ $I D E$ isoform compared with the $15 \mathrm{~b} I D E$ isoform. To validate mechanisms of IDE regulation in vivo, we analysed IDE mRNA levels in biopsies of subcutaneous adipose tissue under conditions of controlled hyperinsulinaemia combined with euglycaemia and hyperglycaemia. We detected a trend to increased IDE expression in subcutaneous adipose tissue during clamp experiments, which did not reach statistical significance.

The observed increase in IDE activity after insulin treatment in human hepatoma cells under normal glucose concentration obviously switches off the action of insulin: insulin induces an increase in IDE activity which leads to increased insulin degradation and decreased insulin signalling. However, we detected no regulation of IDE mRNA and protein levels by insulin at normal glucose concentration. The binding of some peptide substrates to one of the IDE subunits is known to lead to allosteric regulation of IDE activity, with the induction of a shift of the IDE dimer/ tetramer equilibrium to the more active dimer and activation of the adjacent subunit [29]. However, insulin binding was shown to induce no activation of IDE, probably because insulin, which is a dimer of A and B chains, can simultaneously bind to both subunits of the IDE dimer. Thus, the effect observed in our experiments cannot be explained by this mechanism.

Under conditions of high glucose, we observed a loss of insulin-induced changes in IDE activity accompanied by an increase in $I D E$ gene expression. We were able to detect an
C

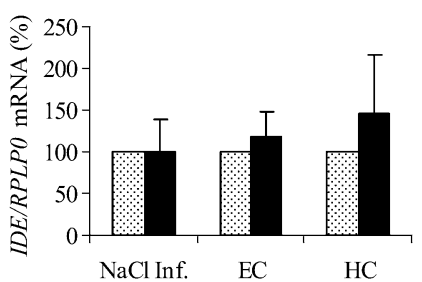

start of clamp tests; black columns, biopsy samples taken at $240 \mathrm{~min}$ of clamp tests. EC, euglycaemic-hyperinsulinaemic clamps; $\mathrm{NaCl}$ Inf., $\mathrm{NaCl}$ infusion; $\mathrm{HC}$, hyperglycaemic-hyperinsulinaemic clamps. $* p<0.05 ; * * p<0.01 ; * * * p<0.001$

insulin-induced increase in $I D E$ mRNA level and a trend to increased IDE protein level. This observation is supported by data from a hyperglycaemic-hyperinsulinaemic clamp study, in which there were similar changes in IDE mRNA levels in subcutaneous fat tissue in vivo. It is possible that the deficit in IDE activity at a high glucose concentration may lead to a compensatory increase in $I D E$ expression. A study carried out in primary hippocampal neuron culture suggested that insulin may induce the increase in IDE protein level through the phosphatidylinositol-3 kinase pathway; however, the glucose concentration in the culture medium was not stated [30].

Our findings suggest that hyperglycaemia itself provokes the known disturbance of IDE activity in type 2 diabetes. Results of analyses of IDE activity in biological fluids (blood cells, plasma, wound fluid, cerebrospinal fluid) of diabetic patients reported in the literature are controversial and apparently depend on a range of factors, including study design, the type of diabetes mellitus and the type of treatment for diabetes. One of the studies showed that IDE activity of erythrocytes was increased in patients with type 2 diabetes taking sulfonylureas, in a subgroup with wellcontrolled type 2 diabetes, and in patients with secondary failure of response to oral therapy, but it was unmodified in well-controlled type 1 diabetic patients [31]. In another study an increase in IDE activity in plasma and erythrocytes was demonstrated both in insulin-dependent and in noninsulin-dependent diabetic patients [32]. In rodents, a decrease in hepatic insulin degradation was observed in diabetic rats, which was restored to near normal levels following insulin treatment $[25,33]$.

Results of the present study suggest that the increase in IDE activity after insulin treatment and the disturbance of this regulation at a high glucose concentration cannot be explained by observed changes in $I D E$ gene expression. To study other possible mechanisms of alteration of IDE activity under high glucose, we investigated the expression of alternative $I D E$ isoforms in cell samples. No alternative splicing forms of IDE of different sizes were detected after 
insulin and/or glucose treatment. Furthermore, insulin significantly increased the level of the more catalytically active 15 a $I D E$ isoform in comparison with the $15 \mathrm{~b} I D E$ isoform in both normal and high glucose conditions. Thus, the regulation of the $15 \mathrm{a} / 15 \mathrm{~b}$ isoform ratio may be one of the mechanisms of the increase in IDE activity after insulin treatment in normal glucose conditions. However, under high glucose conditions, loss of the effect of insulin on IDE activity was observed in the presence of an increased 15a/ $15 \mathrm{~b}$ isoform ratio. Hence, the cause of this effect remains unidentified. Incubation of HepG2 cells in a high glucose concentration was shown to induce insulin resistance [27], which may result in the observed disturbance of regulation of IDE activity by insulin.

A range of chemical substances are known to inhibit IDE activity (chelators, divalent cations, insulin-binding inhibitors and thiol-blocking agents) [6]. The IDE activity in cells may also be regulated by non-esterified fatty acids [34], nucleotide triphosphates [35] and post-translational modification [36]. In particular, ATP induces conformational and aggregation changes in IDE and inhibits insulin degradation in vitro [37]. Therefore, the increase in intracellular ATP in high glucose conditions might result in inhibition of the insulin-degrading activity of IDE. Moreover, IDE-interacting proteins might play a role in the disturbance of regulation of IDE activity in high glucose conditions. The recently described IDE interaction with the mitochondrial protein SIRT4 can alter IDE protease activity by ADP-ribosylation [38]. IDE participates in a functional interaction with the $26 \mathrm{~S}$ proteasome, which is regarded as the principal site of ubiquitin-dependent intracellular protein degradation [39]. Two IDE-interacting proteins (14 and $6 \mathrm{kDa}$ ) were described to inhibit its insulin-degrading activity in rodents, and one of them was identified as ubiquitin [40, 41].

Interestingly, functional changes in IDE were recently described in people with late-onset Alzheimer's disease. Kim et al. [28] found reduced IDE activity, but unaltered $I D E$ expression, in Alzheimer's disease patients from chromosome 10-linked families, suggesting the possibility of systemic functional defects in IDE activity in these families. Type 2 diabetes and hyperinsulinaemia are known to increase the risk of Alzheimer's disease developing in the elderly [42]. Late-onset Alzheimer's disease is also an IDE gene-associated disease, and IDE is the possible link between the pathogenesis of type 2 diabetes and that of late-onset Alzheimer's disease [42]. Therefore, IDE is an attractive drug target for the treatment of type 2 diabetes and Alzheimer's disease. Shen et al. [43] described highresolution crystal structures of IDE, and these authors considered that this opened the door to the design of pharmacological modulators of IDE activity. The disturbance of insulin-induced regulation of IDE activity in high glucose conditions revealed in present study confirms the need to develop IDE activators, as advocated in a recent paper in Nature [44].

In summary, we demonstrated the regulation of IDE activity by insulin in a liver cell model and the loss of this regulation in high glucose conditions. This disturbance cannot be explained by corresponding alterations in IDE protein expression or IDE splicing. Moreover, we detected an insulin-induced increase in IDE mRNA levels and a trend to increased IDE protein level under high glucose conditions. Similar changes in $I D E$ expression in subcutaneous fat tissue in vivo in hyperglycaemic-hyperinsulinaemic clamp experiments were observed. The loss of insulin-induced regulation of IDE activity under high glucose conditions may contribute to reduced insulin extraction and peripheral hyperinsulinaemia in type 2 diabetes.

Acknowledgements We thank all study participants for their cooperation. We gratefully acknowledge the technical assistance of A. Wagner, S. Grosch, A. Ziegenhorn and K. Sprengel. We thank K. Wagner and A. Teichmann for help in the measurement of IDE activity. This study was supported by a grant from the German Research Foundation (DFG Grant No. Pf164/021002; N. Rudovich, Ö. Gögebakan and A. F. H. Pfeiffer) and by the German Academic Exchange Service (O. Pivovarova).

Duality of interest The authors declare that there is no duality of interest associated with this manuscript.

\section{References}

1. DeFronzo RA (1992) Pathogenesis of type 2 (non-insulin dependent) diabetes mellitus: a balanced overview. Diabetologia 35:389-397

2. Rudovich NN, Rochlitz HJ, Pfeiffer AFHP (2007) Reduced hepatic insulin extraction in response to gastric inhibitory polypeptide compensates for reduced insulin secretion in normal-weight and normal glucose tolerant first-degree relatives of type 2 diabetic patients. Diabetes 53:2359-2365

3. Bonora E, Zavaroni I, Coscelli C, Butturini U (1983) Decreased hepatic insulin extraction in subjects with mild glucose intolerance. Metabolism 32:438-446

4. Trischitta V, Brunetti A, Chiavetta A, Benzi L, Papa V, Vigneri R (1989) Defects in insulin-receptor internalization and processing in monocytes of obese subjects and obese NIDDM patients. Diabetes 38:1579-1584

5. Arslanian SA, Saad R, Lewy V, Danadian K, Janosky J (2002) Hyperinsulinemia in African-American children: decreased insulin clearance and increased insulin secretion and its relationship to insulin sensitivity. Diabetes 51:3014-3019

6. Duckworth WC, Bennett RG, Hamel FG (1998) Insulin degradation: progress and potential. Endocr Rev 19:608-624

7. Vekrellis K, Ye Z, Qiu WQ et al (2000) Neurons regulate extracellular levels of amyloid beta-protein via proteolysis by insulin-degrading enzyme. J Neurosci 20:1657-1665

8. Farris W, Leissring MA, Hemming ML, Chang AY, Selkoe DJ (2005) Alternative splicing of human insulin-degrading enzyme yields a novel isoform with a decreased ability to degrade insulin and amyloid beta-protein. Biochemistry 44:6513-6525 
9. Fawcett J, Permana PA, Levy JL, Duckworth WC (2007) Regulation of protein degradation by insulin-degrading enzyme: analysis by small interfering RNA-mediated gene silencing. Arch Biochem Biophys 468:128-133

10. Kupfer S, Wilson EM, French FS (1994) Androgen and glucocorticoid receptors interact with insulin degrading enzyme. J Biol Chem 269:20622-20628

11. Hamel FG, Bennett RG, Upward JL, Duckworth WC (2001) Insulin inhibits peroxisomal fatty acid oxidation in isolated rat hepatocytes. Endocrinology 142:2702-2706

12. Kuo WL, Montag AG, Rosner MR (1993) Insulin-degrading enzyme is differentially expressed and developmentally regulated in various rats tissues. Endocrinology 132:604-611

13. Ghosh S, Watanabe RM, Valle TT et al (2000) The FinlandUnited States investigation of non-insulin-dependent diabetes mellitus genetics (FUSION) study. I. An autosomal genome scan for genes that predispose to type 2 diabetes. Am J Hum Genet 67:1174-1185

14. Meigs JB, Panhuysen CI, Myers RH, Wilson PW, Cupples LA (2002) A genome-wide scan for loci linked to plasma levels of glucose and $\mathrm{HbA}(1 \mathrm{c})$ in a community-based sample of Caucasian pedigrees: the Framingham Offspring Study. Diabetes 51:833-840

15. Karamohamed S, Demissie S, Volcjak J et al (2003) Polymorphisms in the insulin-degrading enzyme gene are associated with type 2 diabetes in men from the NHLBI Framingham Heart Study. Diabetes 52:1562-1567

16. Gu HF, Efendic S, Nordman S et al (2004) Quantitative trait loci near the insulin-degrading enzyme (IDE) gene contribute to variation in plasma insulin levels. Diabetes 53:2137-2142

17. Sladek R, Rocheleau G, Rung J et al (2007) A genome-wide association study identifies novel risk loci for type 2 diabetes. Nature 445:881-885

18. Kwak SH, Cho YM, Moon MK et al (2008) Association of polymorphisms in the insulin-degrading enzyme gene with type 2 diabetes in the Korean population. Diabetes Res Clin Pract 79:284-290

19. Farris W, Mansourian S, Chang Y et al (2003) Insulin-degrading enzyme regulates the levels of insulin, amyloid beta-protein, and the beta-amyloid precursor protein intracellular domain in vivo. Proc Natl Acad Sci U S A 100:4162-4167

20. Farris W, Mansourian S, Leissring MA et al (2004) Partial loss-offunction mutations in insulin-degrading enzyme that induce diabetes also impair degradation of amyloid beta-protein. Am J Pathol 164:1425-1434

21. Bennett RG, Hamel FG, Duckworth WC (2003) An insulindegrading enzyme inhibitor decreases amylin degradation, increases amylin-induced cytotoxicity, and increases amyloid formation in insulinoma cell cultures. Diabetes 52:2315-2320

22. Seta KA, Roth RA (1997) Overexpression of insulin degrading enzyme: cellular localization and effects on insulin signaling. Biochem Biophys Res Commun 231:167-171

23. Rubenstein AH, Pottenger LA, Mako M, Getz GS, Steiner DF (1972) The metabolism of proinsulin and insulin by the liver. J Clin Invest 51:912-921

24. Jurcovicová J, Németh S, Vigas M (1977) Effect of insulin and glucose on the activity of insulin-degrading enzymes in rat liver. Endocrinol Exp 11:209-213

25. Nikolaev SL, Strelkova MA, Komov VP (2001) Insulin degradation in hepatocytes and erythrocytes of rats in normal condition and in experimental diabetes. Vopr Med Khim 47:329-337

26. Li CZ, Zhang SH, Shu CD, Ren W (2002) Relationship between insulin-degrading enzyme activity and insulin sensitivity in cell model of insulin-resistance. Di Yi Jun Yi Da Xue Xue Bao 22:151-154

27. Zang M, Zuccollo A, Hou X et al (2004) AMP-activated protein kinase is required for the lipid-lowering effect of metformin in insulin-resistant human HepG2 cells. J Biol Chem 279:4789847905

28. Kim M, Hersh LB, Leissring MA et al (2007) Decreased catalytic activity of the insulin-degrading enzyme in chromosome 10linked Alzheimer disease families. J Biol Chem 282:7825-7832

29. Song ES, Juliano MA, Juliano L, Hersh LB (2003) Substrate activation of insulin-degrading enzyme (insulysin). A potential target for drug development. J Biol Chem 278:49789-49794

30. Zhao L, Teter B, Morihara $\mathrm{T}$ et al (2004) Insulin-degrading enzyme as a downstream target of insulin receptor signaling cascade: implications for Alzheimer's disease intervention. J Neurosci 24:11120-11126

31. Standl E, Kolb HJ (1984) Insulin degrading enzyme activity and insulin binding of erythrocytes in normal subjects and type 2 (non-insulin-dependent) diabetic patients. Diabetologia 27:1722

32. Snehalatha C, Timothy H, Mohan V, Ramachandran A, Viswanathan M (1990) Immunoreactive insulin and insulin degrading enzymes in erythrocytes. A preliminary report. J Assoc Physicians India 38:558-561

33. Hern EP, Shroyer LA, Varandani PT (1987) Insulin-degrading neutral cysteine proteinase activity of adipose tissue and liver of nondiabetic, streptozotocin-diabetic, and insulin-treated diabetic rats. Arch Biochem Biophys 254:35-42

34. Hamel FG, Upward JL, Bennett RG (2003) In vitro inhibition of insulin-degrading enzyme by long-chain fatty acids and their coenzyme A thioesters. Endocrinology 144:2404-2408

35. Song ES, Juliano MA, Juliano L, Fried MG, Wagner SL, Hersh LB (2004) ATP effects on insulin-degrading enzyme are mediated primarily through its triphosphate moiety. J Biol Chem 279:54216-54220

36. Udrisar DP, Wanderley MI (1992) Fluoride and phosphatidylserine induced inhibition of cytosolic insulin-degrading activity. Acta Physiol Pharmacol Ther Latinoam 42:183-196

37. Del Carmen Camberos M, Cresto JC (2007) Insulin-degrading enzyme hydrolyzes ATP. Exp Biol Med (Maywood) 232:281292

38. Ahuja N, Schwer B, Carobbio S et al (2007) Regulation of insulin secretion by SIRT4, a mitochondrial ADP-ribosyltransferase. J Biol Chem 282:33583-33592

39. Bennett RG, Hamel FG, Duckworth WC (2000) Insulin inhibits the ubiquitin-dependent degrading activity of the $26 \mathrm{~S}$ proteasome. Endocrinology 141:2508-2517

40. Saric T, Muller D, Seitz HJ, Pavelic K (2003) Non-covalent interaction of ubiquitin with insulin-degrading enzyme. Mol Cell Endocrinol 204:11-20

41. Ogawa W, Shii K, Yonezawa K, Baba S, Yokono K (1992) Affinity purification of insulin-degrading enzyme and its endogenous inhibitor from rat liver. J Biol Chem 267:1310-1316

42. Qiu WQ, Folstein MF (2006) Insulin, insulin-degrading enzyme and amyloid-beta peptide in Alzheimer's disease: review and hypothesis. Neurobiol Aging 27:190-198

43. Shen Y, Joachimiak A, Rosner MR, Tang WJ (2006) Structures of human insulin-degrading enzyme reveal a new substrate recognition mechanism. Nature 443:870-874

44. Leissring MA, Selkoe DJ (2006) Structural biology: enzyme target to latch on to. Nature 443:761-762 